\title{
Children Songs as A Learning Media Used in Increasing Motivation and Learning Student in Elementary School
}

\author{
Ardian Arief ${ }^{\mathrm{a}, 1, *}$, Faris Isnan ${ }^{\mathrm{b}, 2}$ \\ ${ }^{\text {a }}$ Primary Teacher Education Universitas Sarjanawiyata Tamansiswa Yogyakarta, 55165, Indonesia. \\ ${ }^{\text {b }}$ Universitas Sarjanawiyata Tamansiswa Yogyakarta, 55165, Indonesia. \\ ${ }^{1}$ ardian.arief@ ustjogja.ac.id*; ${ }^{2}$ farisisnan95@gmail.com \\ * corresponding author
}

\section{ARTICLE INFO}

\section{Article history}

Received 2019-10-02

Revised 2019-12-10

Accepted 2020-06-20

\section{Keywords}

Children Songs

Learning Media

Learning Motivation

Elementary School

Educational Technology

\section{ABSTRACT}

Motivation can be a driving force within students that gives rise to learning activities, which ensures continuity of learning activities and which gives direction to learning activities so that the desired goals of the learning subject can be achieved. Students who have strong motivation will have much energy to do learning activities. The results of learning activities will also be optimal if there is the right motivation-media in education functions as a means to achieve learning objectives. Therefore, the information contained in the media must be able to engage students, both mentally and in the form of real activities, so that learning can occur. The use of media in learning in elementary schools can affect student motivation, and the findings evidence this. Differences in learning motivation in thematic learning between the experimental class taught using the learning media of children's songs and the control class taught using classical music learning media, which is seen from the average score of the experimental class at 77.35 and the control class 68.00. From these results, the average experimental class was higher than the control class $(77,35>68.00)$.

This is an open-access article under the CC-BY-SA license.

\section{Introduction}

Education is an individual process to see the socio-cultural conditions, and emphasizes the role of himself holistically in life, to form a quality life attitude [1]. The function of education is to influence the formation of world views, the formulation process of world views occurs through the education process so that in time the frameworks needed in the life process can be formed. The formulation of a framework for worldview is a significant factor in individual development [2]. Related to this, education is a cultural endeavor that intends to guide the life and growth of students' physical and mental well-being so that in their natural lines and environmental influences, they will progress physically and spiritually [3]. From the various presentations, it can be concluded that education is one of the main assets in the lives of students. In the context of learning, a student will be influenced by many factors in the process, and one of these factors is student motivation [4]. Motivation can provide direction in activities that must be done following the formulation of its objectives. Motivation can be a driving force within students that gives rise to learning activities, which ensures continuity of learning activities and which gives direction to learning activities so that the desired goals of the learning subject can be achieved [5]. It is said "overall" because, in general, there are several motives that together move students to learn. Learning motivation is a psychological factor that is nonintellectual [6]. His distinctive role is in terms of growing passion, feeling happy, and eager to learn. Students who have strong motivation will have much energy to do learning activities. The results of learning activities will also be optimal if there is the right motivation [7]. 
The presence of teachers in the learning process, especially in the classroom, becomes essential and strategic. No longer a center of learning, but as a facilitator and motivator [8]. One form of teacher efforts in managing learning is by making learning media as a means to explore scientific concepts from teacher to student. Media in education functions as a means to achieve learning objectives [9]. Therefore, the information contained in the media must be able to engage students, both mentally and in the form of real activities, so that learning can occur. The material must be designed more systematically and psychologically and be reviewed in terms of learning principles in order to prepare practical learning instructions. Besides being fun, learning media must be able to provide a pleasant experience and meet the individual needs of students [10]. At a more real level, several problems occur in elementary schools. An observation conducted at Sampangan Elementary School in Yogyakarta in October 2018, obtained data that some teachers were found to deliver the material using only the lecture method, it was seen that many students were less enthusiastic about learning activities that were taking place, there were still some students talking to their peers, and there were some of the other students only rely on their mood when they take part in learning activities, even though the teacher in delivering class material is already excellent, coherent and uses a loud volume.

These problems indeed become obstacles for learning both for students, teachers, and schools, especially the fifth-grade elementary school in Cluster 1, Banguntapan, Bantul. Alternative $\mathrm{f}$ to make the necessary improvements in media study carried out by the teacher in thematic learning. One of the media that is expected to be able to help students in learning motivation is to utilize children's songs as learning media. Children's songs have some concrete elements which certainly makes the song can motivate children [11]. This is because children's songs have simple musical elements so that children smoothly sing them, children quickly understand the contents of the messages contained in song lyrics, and children's songs have a robust musical aesthetic when sung by children. Integrate theme song of children with learning on thematic learning is expected to have a positive impact on student motivation Primary school on thematic learning in the curriculum, 2013. If examined further, learning media need equipment to present messages. However, the most important thing is not the equipment but the learning messages or information that is delivered by the media [12]. The use of instructional media in the teaching and learning process can arouse new desires and interests, arouse motivation and stimulation of learning activities, and even bring influences psychologically towards students [13].

The media is used to attract attention, so students remain aware and attentive. The clarity of instructional media and the attractiveness of images and the use of special effects are very influential in arousing students' curiosity [14]. This shows if the media has an impact on increasing motivation and interest in learning [15]. Learning becomes more interactive by applying learning theories and psychological principles that are accepted in terms of student participation, feedback, and reinforcement. With instructional media, the length of time used in learning can be shortened because most media only require a short amount of time to deliver messages and lesson content in sufficient quantities and are likely to be more easily absorbed by students. Media has many types, which, of course, have the characteristics of each; one kind of media is audio media. Audio media is the media whose delivery can only be received by the sense of hearing. The message or information to be conveyed is poured into the auditive symbols in the form of words, instrumental music, sound effects, and songs [16].

Song or music is an audio learning media. Music or song is one thing that influences life, including children. Often we see a child who pauses from his activities just because he listens to a song on television, and then he focuses on watching television. Some children eagerly sing songs that he often hears when they are taking a bath, eating, before going to sleep, or playing [17]. The uniqueness of the sounds of musical instruments and the singer's voice makes the song have the psychological power to move the feelings as well as the emotional expression of anyone who hears it, to make the listener feel happy, sad, calm, comfortable, peaceful and so forth [18]. Children's songs as a person's consumption at the level of children (pre-school and elementary school) have an essential role in the development of thinking [19]. Because the lyrics and tones used in this type of song have indeed been designed according to students' minds. According to Adachi, children's songs are understood as songs that are commonly or often sung by children. Children's song poetry contains simple things that are usually done by children [20].

Furthermore, according to Muwati, children's songs are songs that are cheerful and reflect high ethics [21]. Based on Kim's opinion, it can be concluded that children's songs teach good things or 
moral values, or nowadays, it is often called having character education [22]. In other words, one important feature found in children's songs, which teaches good behavior through the imagination of the music it receives. Child songs not only introduced as entertainment, will but also use it to pick up the message and meaning in learning [23]. In the context discussed in the previous paragraph, it is quite clear that audio media in the form of children's songs can be useful as an alternative to encouraging student motivation and learning. In learning activities, motivation can be said to be the overall driving force within students that gives rise to learning activities, which ensures continuity of learning activities and which gives direction to learning activities [24], so that the desired goals of the learning subject can be achieved. It is said "overall" because, in general, there are several motives that together move students to learn. Learning motivation is a psychological factor that is non-intellectual [6]. His distinctive role is in terms of growing passion, feeling happy, and eager to learn. Students who have strong motivation will have much energy to do learning activities [25]. Motivation is a complex problem, motivation will cause a change in the energy that exists in humans, so that it will cling to the problem of mental symptoms, feelings, and emotions, to then act or do something. All of this is driven because of goals, needs, or desires. Motivation can also be said to be a series of efforts to provide certain conditions, so someone wants and wants to do something [26].

\section{Method}

This research was conducted at the Elementary School in Yogyakarta. The primary schools used are in Banguntapan Bantul District, consisting of Sampangan Elementary School and MI Grojogan. The research was conducted in June 2018 until April 2019. The design used in this study was a nonequivalent control group design with two groups of subjects, namely the experimental group and the control group that was given different treatments, shown in Table 1. Both groups were given a pretest and posttest to find out the initial state and circumstances end is there a difference between the two groups [27].

Table. 1 Design Study

\begin{tabular}{ccccc}
\hline Group & & Pretest t & $\begin{array}{c}\text { Dependent } \\
\text { variable }\end{array}$ & Posttest t \\
\hline $\begin{array}{c}\text { Sampangan Elementary } \\
\text { School }\end{array}$ & Experiment & $\mathrm{O}_{1}$ & $\mathrm{X}$ & $\mathrm{O}_{2}$ \\
\hline MI Grojogan & Control & $\mathrm{O}_{1}$ & $\mathrm{X}_{2}$ & $\mathrm{O}_{2}$ \\
\hline
\end{tabular}

Information:

$$
\begin{aligned}
& \mathrm{O}_{\text {1: }} \text { Pre Test Value (before treatment) } \\
& \mathrm{O}_{2:} \text { Post Test Value (after treatment is given) }
\end{aligned}
$$

$\mathrm{X}$ : Treatment of research using the media of children's songs

$\mathrm{X}_{2}$ : Learning to use traditional music media.

In this study, the population was all fifth-grade students of odd semester elementary school in cluster 01 of Banguntapan district, Bantul. Population data appear in Table 2.

Table 2. Data Of Fifth-Grade Elementary School Students In Group 1, Banguntapan District, Bantul

\begin{tabular}{cc}
\hline School name & Total students \\
\hline Sampangan Elementary School & 70 \\
\hline MI Grojogan & 75 \\
\hline Amount & 145 \\
\hline
\end{tabular}

The research sample was taken as many as two elementary schools from six primary schools using a purposive random sampling technique. Then after being selected two schools, the study sample was taken randomly using a cluster random sampling technique to take a sample of two groups that had the same characteristics randomly. The experimental group and the control group were determined by drawing four classes in the two elementary schools. The sample for this study was fifth-grade Sampangan elementary school and fifth grade MI Grojogan. The class that became the experimental class was class V Sampangan Elementary School, while for the control class V MI Grojogan. The 
purpose of this research was to determine the effect of the use of children's song learning media on student motivation in the thematic subjects of class V SD S e-Cluster 01, Banguntapan, Bantul. Therefore, to know this, the description of the data in this study was obtained from data in the form of questionnaire tests of student motivation in the thematic subjects of class V SD S e-Cluster 01, Banguntapan Bantul sub-district after being treated ( posttest). The learning motivation questionnaire was first tested to find out whether each item was valid or not. The instrument trials were conducted separately to be proven empirically. The number of things to test the learning motivation questionnaire instrument was 36 items. Of the 36 subjects after testing the device, 13 statements were dropped, and 23 subjects were valid.

\section{Results and Discussion}

In this research, the proposed hypothesis is: There is a difference in students' learning motivation in the thematic subjects of class V Elementary School 01 Cluster Banguntapan Bantul between students who are taught using children's song learning media and those taught using classical music learning media. Based on the calculation of the hypothesis, the data obtained that there are differences in student motivation to use learning media for children's songs with classic songs, along with the data. The results can be seen in Table 3 .

Table 3. Hypothesis Testing Results

\begin{tabular}{ccccccc}
\hline Class & $\boldsymbol{N}$ & Average & $\boldsymbol{P}$. & $\boldsymbol{t}_{\text {count }}$ & $\boldsymbol{t}_{\text {table }}$ & Information \\
\hline Experiment & 28 & 77,35 & & & & $\begin{array}{c}\text { There are } \\
\text { Cignificant }\end{array}$ \\
& & & 0,000 & 6,440 & 1,672 & \begin{tabular}{c} 
Sifferences \\
\hline Control
\end{tabular} \\
\hline
\end{tabular}

Based on these data, the description of the results of this research hypothesis can be described in detail as follows.

\subsection{Descriptive}

\subsubsection{The tendency of students' motivation in thematic learning is taught using children's song learning media.}

The tendency of learning motivation of Sampangan Elementary School V grade students totaling 28 students as an experimental class taught using the learning media of children's songs obtained an average score of 77.35 and the standard deviation of 2.921368093 . The average value of 77,35 in the standard curve criteria, is in the medium category with intervals between $75.88931595 \leftrightarrow$ 78.81068405. Thus, students' motivation in the thematic subjects of the experimental class with the learning media of children's songs has a moderate tendency. Learning that uses children's song learning media more attracts the attention of students. Students look very enthusiastic when the delivery of learning material is delivered through songs. The lyrics in the song are taken from news reading material contained in student books. Students quickly understand what the content contained in the reading; this is seen when students are given questions about the reading can immediately answer quickly and correctly. Questions about the reading are also conveyed through a song. Children's songs are appropriate for use in elementary school learning because children's songs are created from elements that are simple and cheerful in terms of both lyrics and music so that they are easily understood and accepted by elementary school students to be more enthusiastic in participating in learning.

\subsubsection{The tendency of students' motivation in thematic learning is taught using classical music learning media.}

The tendency of learning motivation of Sampangan Elementary V grade students totaling 31 students as a control class taught using classical music learning media obtained an average score of 68.00 and the standard deviation of 2.943920289 . The average value of 68,00 , in the criteria of the standard curve in a category is the interval between $\leftrightarrow 66.5280398669 .47196014$. Thus, students' motivation in the thematic subjects of the control class with classical music learning media has a moderate tendency. Learning in the control class uses classical music as accompaniment in students' reading activities. Reading material read by students in the control class is the same as student reading in the experimental class, but with different media. In this case, the traditional music media is used as 
accompaniment when students read. Classical music has an arrangement of beautiful tunes that are played regularly that can turn chaos and disharmony into order, consistency, the logic of inspiration, and excitement. By playing classical music when the reading process, students become more focused and concentrated, so students are easier to understand the contents of the reading, he is reading. This was seen when students were asked about how they felt when reading while listening to classical music; most students answered that they felt calmer, more comfortable, and more concentrated.

\subsubsection{Comparatively}

Based on the results of the study obtained an average score of pretest for the experimental class of 69,32 , whereas the control class obtained an average pretest score of 63,58 , after being given treatment in the form of the use of children's song learning media for the experimental class and the purpose of classical music learning media for the control class, an average score of posttest 77 was obtained, 35 for the innovative grade and an average posttest score of 68.00 for the control class. Based on these data, the two types both experienced an increase in the posttest score after being treated, but the experimental class got the posttest score higher than the control class. So it can be said that students' learning motivation in the innovative class by using children's song learning media is more top. The conclusion obtained is the thematic learning in class V in group 01 of Banguntapan Bantul District will be more productive, enjoyable. It can increase student motivation if the learning process uses children's song learning media.

\section{Conclusion}

Based on the data collected and the results of the analysis presented in the previous chapter to test the hypothesis, the researcher formulated the following conclusions. There is a difference in learning motivation in thematic learning between the experimental class taught using the learning media of children's songs and the control class taught using classical music learning media, which is seen from the average score of the experimental quality of 77,35 and the control class of 68.00. From these results, the average innovative level was higher than the control class $(77,35>68.00)$. There is an influence of students' learning motivation that is taught by using the media of learning of children's songs and students who are trained to use classical music learning media. This can be seen from the acquisition of $\mathrm{T}$ count $=6.440$ and $\mathrm{T}$ table $=1.672$. So it can be concluded that the $\mathrm{T}$ count is greater than the T table; in other words, there is an influence of learning motivation on thematic learning).

\section{References}

[1] E. R. Kahu, "Framing student engagement in higher education," Stud. High. Educ., vol. 38, no. 5, pp. 758 773, Jun. 2013, doi: 10.1080/03075079.2011.598505.

[2] H. B. Danesh, "Towards an integrative theory of peace education," J. Peace Educ., vol. 3, no. 1, pp. 5578, Mar. 2006, doi: 10.1080/17400200500532151.

[3] C. M. Shields, "Liberating Discourses: Spirituality and Educational Leadership," J. Sch. Leadersh., vol. 15, no. 6, pp. 608-623, Nov. 2005, doi: 10.1177/105268460501500601.

[4] T. Seifert, "Understanding student motivation," Educ. Res., vol. 46, no. 2, pp. 137-149, Jun. 2004, doi: $10.1080 / 0013188042000222421$.

[5] S. Pew, "Andragogy and Pedagogy as Foundational Theory for Student Motivation in Higher Education," InSight A J. Sch. Teach., vol. 2, pp. 14-25, Aug. 2007, doi: 10.46504/02200701pe.

[6] P. L. Mihaela, "Psychological Factors of Academic Success," Procedia - Soc. Behav. Sci., vol. 180, pp. 1632-1637, May 2015, doi: 10.1016/j.sbspro.2015.02.318.

[7] R. J. Vallerand, "From motivation to passion: In search of the motivational processes involved in a meaningful life.," Can. Psychol. Can., vol. 53, no. 1, pp. 42-52, 2012, doi: 10.1037/a0026377.

[8] A. F. Grasha, "A Matter of Style: The Teacher as Expert, Formal Authority, Personal Model, Facilitator, and Delegator," Coll. Teach., vol. 42, no. 4, pp. 142-149, Oct. 1994, doi: $10.1080 / 87567555.1994 .9926845$.

[9] B. C. Bruce and J. A. Levin, "Educational Technology: Media for Inquiry, Communication, Construction, and Expression," J. Educ. Comput. Res., vol. 17, no. 1, pp. 79-102, Jul. 1997, doi: 10.2190/7HPQ-4F3X$\underline{8 \mathrm{M} 8 \mathrm{Y}-\mathrm{TVCA}}$. 
[10]D. E. Baird and M. Fisher, "Neomillennial User Experience Design Strategies: Utilizing Social Networking Media to Support “Always on 'Learning Styles,” J. Educ. Technol. Syst., vol. 34, no. 1, pp. 5-32, Sep. 2005, doi: 10.2190/6WMW-47L0-M81Q-12G1.

[11]M. Brumen, "The perception of and motivation for foreign language learning in pre-school," Early Child Dev. Care, vol. 181, no. 6, pp. 717-732, Jul. 2011, doi: 10.1080/03004430.2010.485313.

[12]R. E. Mayer, “The promise of multimedia learning: using the same instructional design methods across different media," Learn. Instr., vol. 13, no. 2, pp. 125-139, Apr. 2003, doi: 10.1016/S09594752(02)00016-6.

[13]L. Holtzman, "Mining the invisible: Teaching and learning media and diversity," Am. Behav. Sci., vol. 48, no. 1, pp. 108-118, Sep. 2004, doi: $\underline{10.1177 / 0002764204267256}$.

[14] M. P. Arnone, R. V. Small, S. A. Chauncey, and H. P. McKenna, "Curiosity, interest and engagement in technology-pervasive learning environments: a new research agenda," Educ. Technol. Res. Dev., vol. 59, no. 2, pp. 181-198, Apr. 2011, doi: 10.1007/s11423-011-9190-9.

[15] M. Liu, L. Horton, J. Olmanson, and P. Toprac, "A study of learning and motivation in a new media enriched environment for middle school science,” Educ. Technol. Res. Dev., vol. 59, no. 2, pp. 249-265, Apr. 2011, doi: 10.1007/s11423-011-9192-7.

[16]P. G. Christenson, P. Debenedittis, and T. R. Lindlof, "Children's use of audio media," Communic. Res., vol. 12, no. 3, pp. 327-343, Jul. 1985, doi: $10.1177 / 009365085012003005$.

[17] M.-Y. Liao and P. S. Campbell, “Teaching children's songs: a Taiwan-US comparison of approaches by kindergarten teachers," Music Educ. Res., vol. 18, no. 1, pp. 20-38, Jan. 2016, doi: 10.1080/14613808.2015.1049256.

[18] S. R. Livingstone and F. A. Russo, "The Ryerson Audio-Visual Database of Emotional Speech and Song (RAVDESS): A dynamic, multimodal set of facial and vocal expressions in North American English," PLoS One, vol. 13, no. 5, p. e0196391, May 2018, doi: 10.1371/journal.pone.0196391.

[19] M. S. Barrett, "Attending to 'culture in the small': A narrative analysis of the role of play, thought and music in young children's world-making," Res. Stud. Music Educ., vol. 38, no. 1, pp. 41-54, Jun. 2016, doi: $10.1177 / 1321103 \times 15603557$.

[20] M. Adachi, S. E. Trehub, and J.-I. Abe, "Perceiving emotion in children's songs across age and culture 1," Jpn. Psychol. Res., vol. 46, no. 4, pp. 322-336, Nov. 2004, doi: 10.1111/j.1468-5584.2004.00264.X.

[21] I. Muwati and D. E. Mutasa, “An analysis of selected Shona children's songs: Philosophical perspectives on child development,” Muziki, vol. 5, no. 1, pp. 1-10, Jul. 2008, doi: 10.1080/18125980802633086.

[22] S. M. Kim and H. J. Kim, “The Impact of Integrated Character Education Activities Involving Children's Songs on Children's Emotional Intelligence and Empathic Ability," Korean J. Childcare Educ., vol. 11, no. 2, pp. 239-260, Apr. 2015, doi: 10.14698/jkcce.2015.11.2.239.

[23] T. Kullenberg and N. Pramling, "Learning and knowing songs: a study of children as music teachers," Instr. Sci., vol. 44, no. 1, pp. 1-23, Feb. 2016, doi: 10.1007/s11251-015-9361-X.

[24]H. Jang, "Supporting students' motivation, engagement, and learning during an uninteresting activity.," $J$. Educ. Psychol., vol. 100, no. 4, pp. 798-811, 2008, doi: 10.1037/a0012841.

[25] S. Linstead and J. Brewis, "Passion, Knowledge and Motivation: Ontologies of Desire," Organization, vol. 14, no. 3, pp. 351-371, May 2007, doi: 10.1177/1350508407076149.

[26] T. Curran, A. P. Hill, P. R. Appleton, R. J. Vallerand, and M. Standage, "The psychology of passion: A meta-analytical review of a decade of research on intrapersonal outcomes," Motiv. Emot., vol. 39, no. 5, pp. 631-655, Oct. 2015, doi: 10.1007/s11031-015-9503-0.

[27]Z. Bayram, Ö. Ö. Oskay, E. Erdem, S. D. Özgür, and Ş. Şen, "Effect of Inquiry based Learning Method on Students' Motivation," Procedia - Soc. Behav. Sci., vol. 106, pp. 988-996, Dec. 2013, doi: $\underline{10.1016 / j . s b s p r o .2013 .12 .112 .}$ 